\title{
The Effect of Price Perception and Sales Promotion on the Purchase Decision of the Pertamax Turbo in Palembang City
}

\author{
Catur Suheri \\ Master of Management, Sriwijaya University, Palembang, Indonesia
}

Corresponding author email: catur.suheri@gmail.com

Zakaria Wahab

Lecturer of Magister Management, Economic Faculty, Sriwijaya University, Palembang, Indonesia

Email: zkwahab01@gmail.com

\author{
Marlina Widiyanti \\ Lecturer of Magister Management, Economic Faculty, Sriwijaya University, Palembang, Indonesia \\ Email: marlinawidiyanti68@yahoo.co.id \\ Muchsin Saggaff Shihab \\ Lecturer of Magister Management, Economic Faculty, Sriwijaya University, Palembang, Indonesia \\ Email: muchsin.shihab@bakrie.ac.id
}

\begin{abstract}
This study aimed to determine the effect of price perception and sales promotion on the purchase decision of Pertamax Turbo in the city of Palembang. The population in this study were all consumers who purchased Pertamax Turbo in Palembang in the 2021 period, with as many as 100 respondents using the purposive sampling technique. The multiple linear regression analysis results show that price perception has a positive and significant effect on the purchase decision of Pertamax Turbo in Palembang. Sales promotion has a positive and significant effect on the purchase decision of Pertamax Turbo in the city of Palembang. For the price perception variable, it is expected that the Pertamax Turbo price adjustment will be made to reach all people. In the sales promotion variable, increasing sales by giving discounts/discounts to consumers who purchase Pertamax Turbo is necessary.

Keywords---consumers, pertamax turbo, price perception, purchase decision, sales promotion.
\end{abstract}

\section{Introduction}

The world of business or trade is one of the main focuses in economic growth. Ongoing trade is a marketing process that spearheads its success, so a more profound understanding is needed to examine how a marketing process run by a company can be successful (Suarta et al., 2020). The company's main objective is to seek maximum profit by utilizing existing resources and capabilities so that it can achieve one goal by introducing products through marketing activities by increasing promotion, pricing, quality, distribution, and service to attract consumers to do business purchasing (Sari et al., 2014).

Pertamax Turbo is the flagship product of PT. Pertamina (Persero) with the highest RON (research octane number) of 98 which was developed with Lamborghini to meet the needs of gasoline engine vehicles with high technology with RON 98 and sulfur content below 50 ppm meeting EURO 4 standards also equipped with the PERTATEC formula (Pertamina technology) and ignition boost formula. A formula designed to keep the engine from rusting, making the engine last longer, using more fuel efficiently, and increasing vehicle acceleration. The selection of Pertamax Turbo products by customers who have gasoline-powered cars is currently not often found.

ISSN 2632-944 1

Submitted: 09 October 2021 |Revised: 27 November 2021 | Accepted: 18 December 2021 
Knowing several aspects that consumers consider when choosing this product will benefit producers, namely PT Pertamina (Persero) as material for further evaluation so that sales can ride (Albert et al., 2008; Lee \& Shin, 2010). For consumers, this also provides high benefits in terms of engine performance and comfort while driving (www.pertamina.com).

The business phenomenon in this research, namely, currently PT. Pertamina (Persero) prefers to encourage people to switch to Pertamax fuel oil products than Pertamax Turbo. According to the CEO of Pertamina's Subholding Commercial and Trading, Mas'ud Khamid said that the people's purchasing power was one of the factors that prevented Pertamina from pushing the public to Pertamax Turbo (Laroche et al., 2003; Wakefield \& Barnes, 1996; Lichtenstein et al., 1997). Based on the study, each community's energy consumption for energy needs is only around 5\% - 5.5\% of monthly income. If calculated, the average is around IDR 7,000 to IDR 8.000, and if driven, the price above is around Rp. Ten thousand, then the price will be heavy (Ridwan, 2020). So based on the business phenomenon above, the authors are interested in researching the effect of price perception and sales promotion on the purchase decision of Pertamax Turbo in Palembang (Zhang \& Zhang, 2007; O'Cass, 2000; Chen et al., 2017).

Following the Regulation of the Minister of Environment and Forestry of the Republic of Indonesia Number P.20/MENLHK/SETJEN/KUM.1/3/2017 concerning Quality Standards for Exhaust Gas Emissions for New Type Motor Vehicles Category M, Category N, and Category O which began to be implemented on 10 March 2017 stated that gasoline-engined vehicles must use EURO 4 standard fuel, while until now the type of fuel issued by PT Pertamina (Persero) with EURO 4 standard is the new Pertamax Turbo type. Thus the market potential for this Pertamax Turbo product is quite enormous. Category $\mathrm{M}$ motorized vehicles are motorized vehicles used to transport people. Category $\mathrm{N}$ motor vehicles are motorized vehicles used for the transportation of goods. Category $\mathrm{O}$ motorized vehicle is a towing motor vehicle for towing or outboard. Assuming that the need for vehicle fuel in the city of Palembang is 3.2 liters/day with a total vehicle of 561,840 units (www.satudata.sumselprov.go.id), it takes 53,936 Kiloliters per month while the average sales of Pertamax turbo products in the City Palembang is only 415 kiloliters. Under these conditions, the market potential for increasing sales of Pertamax Turbo in the city of Palembang is still enormous.

Table 1

Pertamax Turbo Sales Realization in Palembang City 2021

\begin{tabular}{|c|c|c|c|c|c|c|c|c|c|c|c|}
\hline No & $\begin{array}{l}\text { Gas Station } \\
\text { Consumers }\end{array}$ & Region & Jan & $\mathrm{Feb}$ & Mar & April & May & Jun & Jul & Aug & Average \\
\hline 1 & $\begin{array}{l}\text { Gas Station } \\
21.30101\end{array}$ & Palembang city & 72 & 80 & 64 & 88 & 72 & 72 & 72 & 88 & 76 \\
\hline 2 & $\begin{array}{l}\text { Gas Station } \\
21.30204\end{array}$ & Palembang city & 32 & 24 & 32 & 40 & 32 & 32 & 32 & 32 & 32 \\
\hline 3 & $\begin{array}{l}\text { Gas Station } \\
24.30103\end{array}$ & Palembang city & 28 & 40 & 36 & 24 & 32 & 32 & 32 & 32 & 32 \\
\hline 4 & $\begin{array}{l}\text { Gas Station } \\
24.30105\end{array}$ & Palembang city & 32 & 32 & 32 & 24 & 32 & 32 & 40 & 32 & 32 \\
\hline 5 & $\begin{array}{l}\text { Gas Station } \\
24.301108\end{array}$ & Palembang city & 16 & 20 & 20 & 20 & 20 & 24 & 20 & 32 & 22 \\
\hline 6 & $\begin{array}{l}\text { Gas Station } \\
24.301111\end{array}$ & Palembang city & 24 & 24 & 40 & 24 & 24 & 32 & 32 & 24 & 28 \\
\hline 7 & $\begin{array}{l}\text { Gas Station } \\
24.301147\end{array}$ & Palembang city & 16 & 8 & 24 & 8 & 16 & 8 & 16 & 16 & 14 \\
\hline 8 & $\begin{array}{l}\text { Gas Station } \\
24.301149\end{array}$ & Palembang city & & & & & & & 8 & 24 & 16 \\
\hline 9 & $\begin{array}{l}\text { Gas Station } \\
24.30115\end{array}$ & Palembang city & 8 & 8 & 8 & 8 & 8 & & & & 8 \\
\hline 10 & $\begin{array}{l}\text { Gas Station } \\
24.30116\end{array}$ & Palembang city & 28 & 24 & 24 & 24 & 20 & 12 & 12 & 24 & 21 \\
\hline 11 & $\begin{array}{l}\text { Gas Station } \\
24.301163\end{array}$ & Palembang city & 16 & & & & & & & & 16 \\
\hline 12 & $\begin{array}{l}\text { Gas Station } \\
24.301174\end{array}$ & Palembang city & 8 & 8 & 12 & 8 & 8 & 8 & 8 & 8 & 9 \\
\hline 13 & Gas Station & Palembang city & & & & & & & & 8 & 8 \\
\hline
\end{tabular}




\begin{tabular}{|c|c|c|c|c|c|c|c|c|c|c|c|}
\hline 14 & $\begin{array}{l}24.301176 \\
\text { Gas Station } \\
24,302.175\end{array}$ & Palembang city & 48 & 52 & 48 & 56 & 64 & 64 & 64 & 72 & 59 \\
\hline 15 & $\begin{array}{l}\text { Gas Station } \\
24.302123\end{array}$ & Palembang city & 4 & 4 & 4 & 4 & 4 & 4 & 4 & 8 & 5 \\
\hline 16 & $\begin{array}{l}\text { Gas Station } \\
24.302129\end{array}$ & Palembang city & 64 & 56 & 64 & 79 & 64 & 48 & 64 & 40 & 60 \\
\hline 17 & $\begin{array}{l}\text { Gas Station } \\
24.302164\end{array}$ & Palembang city & 16 & 16 & 16 & 24 & 16 & 24 & 8 & & 17 \\
\hline & \multicolumn{2}{|c|}{ Grand Total } & 412 & 396 & 424 & 431 & 412 & 392 & 412 & 440 & 415 \\
\hline
\end{tabular}

Data Source: PT Pertamina IT Palembang (In Kiloliter Units), 2021

Table 2

Fuel Price List in Palembang City in 2021

\begin{tabular}{|c|c|c|}
\hline No. & Fuel Type & Price $(\mathrm{Rp})$ \\
\hline 1 & Petalite & 7.850 \\
\hline 2 & Pertamax & 9,200 \\
\hline 3 & Pertamax Turbo & 10.050 \\
\hline 4 & Delete & 9.700 \\
\hline 5 & Pertamina Dex & 10,450 \\
\hline 6 & Non-Subsidized Solar & 9,600 \\
\hline
\end{tabular}

Based on the data in Table 1.1, it can be seen that the price of fuel for the Pertamax Turbo type in Palembang has a higher price of IDR 10,050 when compared to the price of Pertamax fuel of IDR 9,200. The use of Pertamax Turbo is intended for vehicles with gasoline fuel. For owners of high compression vehicles, it is highly recommended to use Pertamax Turbo, even though the price of Pertamax Turbo is higher when compared to the price of Pertamax, Petalite, and Premium prices. This is comparable to what the engine gets because Pertamax Turbo is highly recommended for a better vehicle engine in high compression engines (Aghara et al., 2018).

PT. Pertamina (Persero) promotes the MyPertamina application by providing the promo "Opportunity to Enjoy Great Savings" from 1 May to 31 May 2021. The promo is that consumers can enjoy savings in buying fuel by giving a discount of Rp. 300/ liter by purchasing Pertamax, Pertamax Turbo, Pertamina Dex, and Dexlite products using cashless transactions on the MyPertamina application (www.Pertamina.id).

\section{Research Methods}

The population in this study were all consumers who purchased Pertamax Turbo in the city of Palembang in the period 2021. According to Hair (2010), the sample measurement guidelines can be determined as follows: 1) depending on the number of estimated parameters. The guideline is 5-10 times the number of estimated parameters, 2 ) the number of statements used is as many as items. So the number of samples used in this study with a minimum limit of 15 items x $5=75$ respondents, while the maximum limit of 15 items x $10=150$. Thus, 100 respondents will be taken. This amount is considered sufficient to represent the population to be studied because it has met the maximum limit of the research sample.

\section{Research Result \\ Model Conformity Results (Test F)}

Based on the results of the model suitability test ( $F$ test), obtained a significance value of 0.000 because the significance value is $0.000<0.05$, it can be said that the linear regression model obtained is feasible to be used to explain the effect of price perception and sales promotion on purchasing decisions.

Individual Parameter Significance Test Results (t-Test):

1) The price perception variable (X 1 ) has a beta value of 0.647 with a significant value of 0.000 , more diminutive than 0.05 . This shows that the price perception variable has a positive and significant influence on 
the purchase decision of Pertamax Turbo in the city of Palembang. This proves that the first hypothesis on the price perception variable has a positive and significant effect and can be accepted.

2) The sales promotion variable ( $\mathrm{X} 2$ ) has a beta of 0.207 with a significance value of 0.011 , more diminutive than 0.05 . This shows that the sales promotion variable has a positive and significant influence on the purchase decision of Pertamax Turbo in the city of Palembang. This proves that the second hypothesis on the sales promotion variable has a positive and significant effect and can be accepted.

Price perception has a positive and significant effect on purchasing decisions. These results are in line with the results of research from (Inayah et al., 2019); (Tulanggow et al., 2019); (Wicaksana \& Sri, 2018); (Fernando and Aksari, 2017); (Hendro and Hidayat, 2018); (Pratama and Santoso, 2018); (Wangarry et al., 2018); (Sumiati and Mujanah, 2018); (Polla et al., 2018); (Soebakir et al., 2018); (Maindoka et al., 2018); (Hanifati and Waluyo, 2019); (Hendrianti, 2019); (Sulistyorini \& Rahardjo, 2018); (S and Suryoko, 2017); (Gerung et al., 2017), shows the same result that price has a positive and significant effect on purchasing decisions.

This study indicates that price perception is associated with several indicators such as price affordability, price suitability with product quality, price competitiveness, price suitability with benefits (Alford \& Biswas, 2002; Christandl et al., 2011). The price indicator for Pertamax Turbo is affordable for all, showing the lowest value. It is suspected that the price of Pertamax Turbo in Palembang is IDR 10,050 per liter is still included in the high price category, and not all people will buy it, especially when compared to other options with lower prices such as Pertalite IDR 7,850 per liter and Pertamax IDR 9,200 per liter which indicates a lower price. This has resulted in more consumers choosing to use Pertalite and Pertamax, especially for public transport vehicles that still choose fuel at a lower price. On the indicators, we are interested in buying Pertamax Turbo because the quality follows the price offered, which shows the highest score of 4.85. This shows that consumers who are respondents in this study are interested in buying Pertamax Turbo because the price offered follows the quality of the market share of Pertamax Turbo consumers, who on average use vehicles in the middle-class category.

Sales promotion has a positive and significant effect on purchasing decisions. These results are in line with research results from (Tulanggow et al., 2019); (Utomo and Waluyo, 2018); (Fernando and Aksari, 2017); (Wangarry et al., 2018); (Sumiati and Mujanah, 2018); (Sari et al., 2018); (Syaleh, 2017); (Gerung et al., 2017); (Tito and Budiatmo, 2017); (Puspitasari et al., 2017), showed the same results, namely the promotion variable had a positive and significant effect on purchasing decisions.

The results showed that sales promotion is associated with several indicators such as advertising (advertising), sales promotion (sales promotion), personal selling (personal selling), public relations (public relations), and direct sales (direct marketing). The advertising indicators displayed by PT Bukit Asam, Tbk are attractive and easy to find, showing the lowest values. It is suspected that the display of advertisements for PT Bukit Asam, Tbk's coal is still challenging to find in public places, especially in the introduction of products and types of coal. In the indicator, PT Bukit Asam, Tbk is often a sponsor in several activities or events showing the highest value. This shows that PT Bukit Asam, Tbk is often a sponsor in several activities, making PT Bukit Asam increasingly known.

This study indicates that sales promotions are associated with several indicators such as rebates/discounts, prizes, and points. On the indicator, every time we purchase Pertamax Turbo, a discount/discount is often given, showing the lowest value. It is suspected that consumers feel that PT Pertamina (Persero) still lacks promotions in providing discounts/prices to consumers who purchase fuel, especially the purchase of Pertamax Turbo. The indicator for giving points using the MyPertamina member card shows the highest value. This shows that the awarding of points on the MyPertamina application is one of the attractions for consumers to buy Pertamax Turbo. One of them is PT Pertamina (Persero), a promotion to introduce the MyPertamina member application to the public that can be downloaded on the AppStore and PlayStore. With the development of the MyPertamina application to attract consumers, namely by activating members and purchasing fuel oil at Pertamina gas stations, we will get collected points that can be reused for refueling.

\section{Conclusions}

Price perception and sales promotion have a positive and significant effect on the purchase decision of Pertamax Turbo in the city of Palembang.

Acknowledgments

The author expresses his deep gratitude to the academic parties who have provided support in the form of feedback 


\section{References}

Aghara, V. N. O., Nwaizugbo, I. C., Oparah, P. C., \& Ifeanyichukwu, C. D. (2018). Sales promotion as a leverage strategy for improving sales and profitability in alcohol beverage industry: A study of Nigeria breweries plc. International Research Journal of Management, IT and Social Sciences, 5(4), 18-25. https://doi.org/10.21744/irjmis.v5n4.245

Albert, N., Merunka, D., \& Valette-Florence, P. (2008). When consumers love their brands: Exploring the concept and its dimensions. Journal of Business research,61(10), 1062-1075. https://doi.org/10.1016/j.jbusres.2007.09.014

Alford, B. L., \& Biswas, A. (2002). The effects of discount level, price consciousness and sale proneness on consumers' price perception and behavioral intention. Journal of Business research, 55(9), 775-783. https://doi.org/10.1016/S0148-2963(00)00214-9

Chen, A., Lu, Y., \& Wang, B. (2017). Customers' purchase decision-making process in social commerce: A social learning perspective. International Journal of Information Management,37(6), 627-638. https://doi.org/10.1016/j.ijinfomgt.2017.05.001

Christandl, F., Fetchenhauer, D., \& Hoelzl, E. (2011). Price perception and confirmation bias in the context of a VAT increase. Journal of Economic Psychology, 32(1), 131-141. https://doi.org/10.1016/j.joep.2010.09.006

Fernando, M. F., \& Aksari, N. M. A. (2017). Pengaruh Kualitas Produk, Harga, Promosi, Dan Distribusi Terhadap Keputusan Pembelian Produk Sanitary Ware Toto Di Kota Denpasar (Doctoral dissertation, Udayana University).

Gerung, C. J., Sepang, J., \& Loindong, S. (2017). Pengaruh Kualitas Produk, Harga Dan Promosi Terhadap Keputusan Pembelian Mobil Nissan X-Trail Pada Pt. Wahana Wirawan Manado. Jurnal EMBA: Jurnal Riset Ekonomi, Manajemen, Bisnis dan Akuntansi, 5(2).

Hair. (2010). Multivariate Data Analysis, Seventh Ed. ed. Pearson Prentice Hall.

Handrianti, I. (2019). Pengaruh Persepsi Harga, Citra Merek, Kualitas Produk, dan Promosi Penjualan terhadap Keputusan Pembelian Alat Musik (Studi pada Konsumen Toko Ecayo Yamaha Musik di Bandar Lampung).

Hanifati, F., \& Waloejo, H. D. (2019). Pengaruh harga, brand image, dan kualitas pelayanan terhadap keputusan pembelian (Studi kasus gracia skin clinic Semarang). Jurnal Ilmu Administrasi Bisnis, 8(4), 60-66.

Hendro, C. R., \& Hidayat, W. (2018). Pengaruh Kualitas Produk, Harga dan Citra Merek Terhadap Keputusan Pembelian Konsumen Handphone Merek Iphone Kota Semarang. Jurnal Ilmu Administrasi Bisnis, 7(4), 177-184.

Inayah, D., Zulkarnain, Z., \& Garnasih, R. L. (2019). Analisis pengaruh kualitas produk dan harga terhadap brand image dan keputusan pembelian sepeda motor yamaha mio pada pt. Alfa scorpii kota pekanbaru. Jurnal Tepak Manajemen Bisnis, 11(3).

Laroche, M., Pons, F., Zgolli, N., Cervellon, M. C., \& Kim, C. (2003). A model of consumer response to two retail sales promotion techniques. Journal of Business research, 56(7), 513-522. https://doi.org/10.1016/S01482963(01)00249-1

Lee, K. H., \& Shin, D. (2010). Consumers' responses to CSR activities: The linkage between increased awareness and purchase intention. Public Relations Review, 36(2), 193-195. https://doi.org/10.1016/j.pubrev.2009.10.014

Lichtenstein, D. R., Burton, S., \& Netemeyer, R. G. (1997). An examination of deal proneness across sales promotion types: a consumer segmentation perspective. Journal of Retailing, 73(2), 283-297. https://doi.org/10.1016/S0022-4359(97)90007-5

Maindoka, L. F., Tumbel, A., \& Rondonuwu, C. (2018). Analisis Pengaruh Citra Merek, Harga Dan Desain Produk Terhadap Keputusan Pembelian Mobil Nissan Grand Livina Pada PT. Wahana Wirawan Manado. Jurnal EMBA: Jurnal Riset Ekonomi, Manajemen, Bisnis dan Akuntansi, 6(3).

O'Cass, A. (2000). An assessment of consumers product, purchase decision, advertising and consumption involvement in fashion clothing. Journal of economic psychology, 21(5), 545-576. https://doi.org/10.1016/S01674870(00)00018-0

Polla, F. C., Mananeke, L., \& Taroreh, R. N. (2018). Analisis pengaruh harga, promosi, lokasi dan kualitas pelayanan terhadap keputusan pembelian pada PT. Indomaret Manado Unit Jalan Sea. Jurnal EMBA: Jurnal Riset Ekonomi, Manajemen, Bisnis Dan Akuntansi, 6(4).

Pratama, D. W., \& Santoso, S. B. (2018). Pengaruh Citra Merek, Kualitas Produk dan Harga Terhadap Keputusan Pembelian melalui Kepercayaan Konsumen pada Produk Stuck Original. Diponegoro Journal of Management, 7(2), 139-149.

Puspitasari, A., Astuti, R.D., Kurniani. (2017). Analisis Pengaruh Harga, Keunggulan Produk dan Promosi Terhadap Keputusan Menggunakan Jasa Fumigasi (Studi Kasus PT. Sucofindo Cabang Semarang). Jurnal JOBS Vol. 3 (1).

Ridwan, M. (2020). Mengapa Pertamina Dorong Konsumsi Pertamax Daripada Pertamax Turbo? 
S, A.F., Suryoko, S. (2017). Pengaruh Citra Merek, Kualitas Produk, dan Harga Terhadap Keputusan Pembelian Produk Tas dan Sepatu Charles \& Keith (Studi Kasus Konsumen Charles \& Keith Paragon Semarang). Jurnal Universitas Diponegoro.

Sari, D. Y., Tjahjaningsih, E., \& Hayuningtias, K. A. (2018). Pengaruh Kualitas Produk, Persepsi Harga, Promosi dan Lokasi terhadap Proses Keputusan Pembelian Kapur Barus Merek Bagus (Studi Pada Konsumen Giant Bsb Semarang).

Sari, R. L., Mandey, S. L., \& Soegoto, A. S. (2014). Citra Merek, Harga Dan Promosi Pengaruhnya Terhadap Keputusan Pembelian Perhiasan Emas Pada PT. Pegadaian (Persero) Cabang Manado Utara. Jurnal EMBA: Jurnal Riset Ekonomi, Manajemen, Bisnis dan Akuntansi, 2(2).

Soebakir, B. D., Lumanauw, B., \& Roring, F. (2018). Pengaruh Brand, Harga dan Kualitas Pelayanan Terhadap Keputusan Pelanggan Membeli di Kedai Kopi Gudang Imaji Manado. Jurnal EMBA: Jurnal Riset Ekonomi, Manajemen, Bisnis dan Akuntansi, 6(4).

Suarta, . G. ., Sukada, K. ., \& Suberata, W. . (2020). Comparison effecting of mixture on three meat factors and three culinary sectors on consumers in restaurant Nusa Dua. International Research Journal of Management, IT and Social Sciences, 7(6), 146-152. https://doi.org/10.21744/irjmis.v7n6.1030

Sulistyorini, O. D., \& Rahardjo, S. T. (2018). Pengaruh Kualitas Produk, Variasi Produk, Kesesuaian Harga, Citra Merek Dan Kesadaran Merek Dalam Upaya Meningkatkan Keputusan Pembelian (Studi Kasus pada Strada Coffee Semarang) (Doctoral dissertation, Fakultas Ekonomika dan Bisnis).

Sumiati, S., \& Mujanah, S. (2018). Persepsi Kualitas Produk, Persepsi Harga dan Promosi Terhadap Keputusan Pembelian Tas Sophie Paris pada Mahasiswa. AMAR (Andalas Management Review), 2(2), 1-10.

Syaleh, H. (2017). Pengaruh Kualitas Produk, Harga, Promosi dan Tempat Pendistibusian Terhadap Keputusan Pembelian Sepeda Motor Yamaha Pada Perusahaan Tjahaja Baru Bukittinggi. COSTING: Journal of Economic, Business and Accounting, 1(1), 68-82.

Tito, Y., \& Budiatmo, A. (2017). PENGARUH KUALITAS PRODUK DAN PROMOSI TERHADAP KEPUTUSAN PEMBELIAN (Studi pada Pembeli dan Pengguna Honda Beat Series di Astra Honda Motor Gajahmada Semarang). Jurnal Ilmu Administrasi Bisnis, 6(4), 273-286.

Tulangow, S. G., Tumbel, T. M., \& Walangitan, O. F. (2019). Pengaruh Promosi dan Harga Terhadap Keputusan Pada Pembelian PT. Shopee International Indonesia Di Kota Manado. Jurnal Administrasi Bisnis (JAB), 9(3), 3543.

Utomo, P. B., \& Waloejo, H. D. (2018). Pengaruh Brand Image, Promosi Dan Kualitas Pelayanan Terhadap Keputusan Penggunaan Jasa (Studi Kasus (Penumpang KA Kaligung PT KAI DAOP IV Semarang). Jurnal Ilmu Administrasi Bisnis, 7(4), 155-159.

Wakefield, K. L., \& Barnes, J. H. (1996). Retailing hedonic consumption: a model of sales promotion of a leisure service. Journal of Retailing, 72(4), 409-427. https://doi.org/10.1016/S0022-4359(96)90021-4

Wangarry, C. L., Tumbel, A., \& Karuntu, M. M. (2018). Pengaruh Bauran Pemasaran Terhadap Keputusan Pembelian Sepeda Motor Honda Di Pt. Hasjrat Abadi Ranotana. Jurnal EMBA: Jurnal Riset Ekonomi, Manajemen, Bisnis dan Akuntansi, 6(4).

WICAKSANA, B. S., \& SRI, R. T. A. (2018). Analisis Pengaruh Kualitas Produk, Harga, Celebrity Endorser, dan Desain Produk Terhadap Keputusan Pembelian Sepeda Motor Yamaha Mio M3 di Kota Semarang (Doctoral dissertation, Fakultas Ekonomika dan Bisnis).

Zhang, T., \& Zhang, D. (2007). Agent-based simulation of consumer purchase decision-making and the decoy effect. Journal of business research, 60(8), 912-922. https://doi.org/10.1016/j.jbusres.2007.02.006 